\title{
Koordynacja jako element nowoczesnej opieki nad pacjentem onkologicznym. Specyfika aktywności zawodowej koordynatorów
}

\author{
Aleksandra Kita
}

Studentka studiów doktoranckich w Instytucie Socjologii Uniwersytetu Zielonogórskiego

Adres do korespondencji: Instytut Socjologii Uniwersytet Zielonogórski, al. Wojska Polskiego 69, 65-762 Zielona Góra, aleksandrakita@interia.pl

\section{Abstract}

\section{Coordination as an element of modern medical care in oncology}

The number of patients suffering from chronic diseases, including oncology, has been systematically increasing in recent years. There is a shortage of doctors and nurses in Poland, and the actions taken within the healthcare system, they focus primarily on securing typically medical needs. Staff in medical facilities are often unable to fully meet the needs of patients. For the treatment to be effective, it must be carried out with the participation of a patient who should experience the greatest comfort and sense of security during therapy. The patient should also have full knowledge about his condition and receive information enabling him to find himself in the health care system. Modern medical care should also include non-medical aspects of patient support. Numerous publications indicate the importance of comprehensive healthcare. It is not possible to build an optimal model of care for a chronically ill patient without strengthening medical staff. The experience of people who, since 2015, have been coordinating oncological treatment as part of their duties, indicates that treatment coordination must be formalized and assigned to a specific person should belong to the duties of this professional category in order to deprive this process of signs of randomness. Therefore, it becomes necessary, firstly, to model and define this function precisely, and secondly, to begin the systematic and comprehensive education of future coordinators.

Stowa kluczowe: koordynator, opieka koordynowanta, zawody medyczne

Key words: coordinator, new profession, coordinated care

\section{Wprowadzenie}

W większości krajów wysoko rozwiniętych, które uporały się ze stworzeniem efektywnych mechanizmów finansowania świadczeń medycznych, polityka zdrowotna jest ukierunkowana na budowanie systemów skoncentrowanych na zaspokajaniu potrzeb pacjenta. Stworzenie mechanizmów służących zwiększeniu efektywności użycia dostępnych zasobów, ze szczególnym uwzględnieniem tak zwanych zasobów ludzkich, jest jednym z kluczowych czynników determinujących skuteczność i efektywność systemu lecznictwa. Wraz z odnotowywanym od lat wzrostem długości życia zwiększa się liczba pacjentów, którzy jednocześnie doświadczają wielu chorób, w tym schorzeń przewlekłych. Nowotwory są drugą przyczyną zgonów w Polsce. Dane Głównego Urzędu Statystycznego za 2015 rok wskazują, że liczba nowych zachorowań na choroby nowotworowe sięgnęła wówczas w kraju 163,3 tys., a liczba zgonów z tego tytułu wyniosła 100,6 tys. [1]. Niepokojący jest fakt, że w ciągu ostatnich trzech dekad liczba zachorowań na nowotwory złośliwe wzrosła ponaddwukrotnie [2]. Personel medyczny, z powodu deficytów związanych z bardzo ograniczoną ilością czasu przeznaczonego na obsługę jednego pacjenta, nie jest $\mathrm{w}$ stanie $\mathrm{w}$ pełni zaspokoić realnych potrzeb świadczeniobiorców. Nowoczesna, kompleksowa opieka medyczna powinna uwzględniać także pozamedyczne aspekty wsparcia pacjenta [3]. W kontekście zmian zachodzących w sektorze zdrowia konieczne wydaje się zwrócenie uwagi na kwestię zwiększenia efektywności kształcenia kadr związanych z sektorem ochrony zdrowia. Kształcenie to powinno przekładać się zarówno na rozwój nowych kompetencji personelu, jak i przyczyniać się do zmiany w podejściu do leczenia pacjentów. W konsekwencji tych zmian kompleksowa 
opieka medyczna powinna być zsynchronizowania na każdym etapie, a działania personelu medycznego powinny uwzględniać liczne uwarunkowania całego procesu chorobowego, który zaczyna się przed wystąpieniem objawów choroby. Nowoczesne i efektywne kształcenie, a następnie wykorzystanie tego potencjału powinno dotyczyć nie tylko osób wykonujących zawody medyczne (zwłaszcza lekarzy, pielęgniarek), lecz także przedstawicieli innych dziedzin mających zastosowanie w ochronie zdrowia, przykładowo dietetyków czy opiekunów medycznych.

\section{Cel pracy}

Celem niniejszej pracy jest opis i wstępna analiza procesu tworzenia nowej profesji, to jest k o ordynatora w polskim systemie ochrony zdrowia. Niezbędny do tego jest przegląd strategicznych dokumentów wyznaczających teoretyczne podstawy takich zmian. Przedstawiona analiza wymagała także usystematyzowanej obserwacji pracy osób zajmujących się koordynowaniem leczenia onkologicznego. O wyborze tej funkcji zadecydował fakt, iż dotychczas tylko pacjenci onkologiczni mają zagwarantowaną pomoc wskazanego z imienia i nazwiska koordynatora, co gwarantują im rozwiązania wprowadzone w ramach tak zwanego pakietu onkologicznego. Ponadto od października 2019 roku pacjenci leczący się w placówkach działających na podstawie zasad Breast Cancer Unit (o których obszerniej będzie w dalszej części tekstu) mają prawo korzystać ze wsparcia zarówno koordynatora merytorycznego, jak i koordynatora organizacyjnego. Zakładając zaledwie inicjujący charakter prezentowanych w tekście ustaleń, za podstawę przyjęto analizę zakresu obowiązków i aktywności zawodowej koordynatora w jednym ze szpitali uniwersyteckich w Polsce. Kolejnym z założonych celów tekstu jest zwrócenie uwagi na zmiany $w$ organizacji i podejściu do leczenia pacjentów przewlekle chorych oraz zainicjowanie dyskursu na temat możliwości i potrzeby rzetelnego kształcenia osób mających w przyszłości pełnić funkcję koordynatora.

\section{Metodyka}

Analizie poddano Ustawę z dnia 27 sierpnia 2004 roku o świadczeniach opieki zdrowotnej finansowanych ze środków publicznych (Dz.U. z 2004 roku Nr 210 poz. 2135 z późn. zm.) [4], a także Rozporządzenie Ministra Zdrowia $z$ dnia 22 listopada 2013 roku w sprawie świadczeń gwarantowanych z zakresu leczenia szpitalnego (Dz.U. z 2013 roku poz. 1520 z późn. zm.) [5] oraz Rozporządzenie Ministra Zdrowia z dnia 6 listopada 2013 roku w sprawie świadczeń gwarantowanych z zakresu ambulatoryjnej opieki specjalistycznej (Dz.U. z 2013 roku poz. 1413 z późn. zm.) [6]. W celu opracowania case study wykorzystano ogólnodostępne informacje zamieszczone na stronach internetowych jednostki macierzystej, to jest Regulamin Organizacyjny Szpitala Uniwersyteckiego im. Karola Marcinkowskiego w Zielonej Górze Spółka z ograniczoną odpowiedzialnością [7]. Innym punktem odniesienia były informacje udostępnione na stronach Urzędu Marszałkowskiego, pełniącego funkcję nadzorczą wobec objętej analizą placówki, to jest Uchwała nr X/98/15 Sejmiku Województwa Lubuskiego z dnia 22 czerwca 2015 roku w sprawie zmiany Statutu Szpitala Wojewódzkiego Samodzielnego Publicznego Zakładu Opieki Zdrowotnej im. Karola Marcinkowskiego w Zielonej Górze [8]. Skorzystano także z materiałów i informacji uzyskanych od koordynatora będącego bezpośrednim podmiotem studium przypadku. Ponadto na potrzeby opracowania dokonano przeglądu propozycji programowych uczelni, które przygotowały oferty edukacyjne przeznaczone dla osób, które chciałyby pełnić funkcję koordynatorów leczenia.

\section{Wybrane regulacje dotyczące funkcji koordynatora}

Jesienią 2019 roku organizacja leczenia i diagnostyki onkologicznej jednej z grup nowotworów została oparta na zasadach Breast Cancer Unit (BCU) [9]. Problematyka nowotworów piersi stanowi od wielu lat jeden $\mathrm{z}$ istotnych punktów zainteresowania medycyny [10]. Standard BCU obejmuje tworzenie placówek zapewniających kompleksową diagnostykę oraz indywidualny proces leczenia onkologicznego, realizowany przez onkologów, chirurgów onkologicznych, specjalistów w zakresie chemioterapii i radioterapii, psychologów klinicznych i rehabilitantów. Założeniem tego systemu jest kompleksowość: pacjenci trafiający do ośrodków BCU przechodzą przez proces diagnostyki, następnie leczenia i rehabilitacji, aż po monitoring skuteczności leczenia [11]. Jest prawdopodobne, że w przyszłości inne typy nowotworów złośliwych (w pierwszej kolejności płuc) będą leczone według standardów tożsamych z BCU. Tak zwane unity to jednostki wyspecjalizowane w kompleksowym leczeniu raka piersi, które leczą pacjentów we wszystkich stadiach choroby, oferując najnowocześniejsze metody leczenia raka. Zarówno wśród chorych, jak i personelu nie ma wątpliwości co do ogromnego znaczenia dostępu do informacji w przebiegu procesu leczenia onkologicznego. W warunkach szczegółowych, jakie powinni spełniać świadczeniodawcy realizujący świadczenia gwarantowane diagnostyki i leczenia onkologicznego, stanowiących załącznik nr 1 do Rozporządzenia Ministra Zdrowia z dnia 24 maja 2019 roku zmieniającego rozporządzenie w sprawie świadczeń gwarantowanych z zakresu leczenia szpitalnego (Dz.U. z dnia 7 czerwca 2019 roku poz. 1062) [12], określono, że zarówno w tak zwanych Ośrodkach Raka Piersi, jak i Centrach Kompetencji Raka Piersi przy organizacji udzielania świadczeń powinna zostać uwzględniona funkcja koordynatora merytorycznego (lekarza) oraz koordynatora organizacyjn e go. Zgodnie z zapisami koordynator organizacyjny uczestniczy w posiedzeniach wielodyscyplinarnego zespołu terapeutycznego i odpowiada za terminową realizację planu postępowania, w tym za: (1) ustalanie terminów realizacji poszczególnych modułów świadczenia, (2) przedstawienie w sposób skuteczny, 
przystępny i zrozumiały dla świadczeniobiorcy informacji o terminach realizacji poszczególnych modułów świadczenia. Funkcję koordynatora organizacyjnego może pełnić w szczególności pielęgniarka specjalista $\mathrm{w}$ dziedzinie pielęgniarstwa onkologicznego lub po kursie kwalifikacyjnym w dziedzinie pielęgniarstwa onkologicznego albo w trakcie specjalizacji w dziedzinie pielęgniarstwa onkologicznego, z co najmniej dwuletnim doświadczaniem w realizacji świadczeń dla świadczeniobiorców z diagnozą nowotworu piersi, lub in na osoba spośród personelu, której wiedza i doświadczenie są odpowiednie do realizacji zadań koordynatora organizacyjnego. Kompatybilne z omówionym wyżej dokumentem jest Rozporządzenie Ministra Zdrowia z dnia 23 maja 2019 roku zmieniające rozporządzenie w sprawie świadczeń gwarantowanych z zakresu ambulatoryjnej opieki specjalistycznej (Dz.U. z dnia 7 czerwca 2019 roku poz. 1060) [13]. Świadczeniodawca obliguje ambulatoryjną opiekę specjalistyczną realizującą świadczenia z zakresu tak zwanej kompleksowej opieki onkologicznej nad świadczeniodawcą z nowotworem piersi do wyznaczenia osoby odpowiedzialnej w podmiocie świadczeniodawcy za kontakt z koordynatorem merytorycznym oraz $\mathrm{z}$ koordynatorem organizacyjnym w ośrodku diagnostyki i leczenia nowotworu piersi. W BCU zapewnienie koordynacji jest zatem niezbywalnym warunkiem organizacji świadczeń.

Początki sformalizowania tego zjawiska datują się od 2015 roku, gdyż to właśnie w tym czasie wraz z pakietem onkologicznym do polskich szpitali wprowadzono funkcję koordynatora. Wcześniej system ochrony zdrowia w Polsce nie przewidywał żadnego stanowiska pracy, które umożliwiało koordynację procesu leczenia i sprawowanie bezpośredniej opieki nad pacjentem. Z dniem 1 lipca 2017 roku weszły w życie kolejne, istotne zmiany do Ustawy z dnia 27 sierpnia 2004 roku o świadczeniach opieki zdrowotnej finansowanych ze środków publicznych (Dz.U. z dnia 11 kwietnia 2017 roku poz. 759) [14]. Na podstawie przyjętych modyfikacji ulokowano funkcję koordynatora w przepisach ustawy, definiując go już dość precyzyjnie jako koordynatora leczenia onkologicznego. Empiryczne udokumentowanie opisanych powyżej cech aktywności zawodowej koordynatora stanowi studium przypadku wybranego koordynatora leczenia onkologicznego. Rozwój kompleksowej opieki nad pacjentem onkologicznym doprowadza do przeobrażeń tego stanowiska pracy. Poznanie specyfiki pracy osób pełniących te funkcje może być bardzo przydatne w podejmowaniu działań służących upowszechnieniu skutecznej koordynacji leczenia chorób przewlekłych, nie tylko onkologicznych. Próba znalezienia optymalnych dla pacjenta rozwiązań poparta doświadczeniem prekursorów, a za takich można uznać koordynatorów leczenia onkologicznego, wpisuje się także w założenia opieki koordynowanej, która zgodnie z koncepcją jej twórców powinna stać się standardem w polskim systemie ochrony zdrowia [15].

\section{Studium przypadku}

\section{Implementacja pakietu onkologiczneyo do warunków Szpitala Uniwersyteckiego im. Karola Marcinkowskiego WZielonej Górze Sp. 70.0.}

Na świadczeniodawców, którzy zdecydowali się realizować tak zwaną Szybką Terapię Onkologiczną, nałożono wiele obowiązków. Realizacja pakietu onkologicznego wiązała się między innymi z przygotowaniem i ugruntowaniem rozwiązań organizacyjnych, nawiązaniem współpracy między interesariuszami wewnątrz struktur danych placówek, ale także poza nimi. W opisywanym szpitalu zarządzeniem dyrektora wprowadzone zostały „Procedury postępowania i organizacji Szybkiej Terapii Onkologicznej” oraz „Regulamin kierowania pacjenta na konsylium oraz organizacji pracy związanej z konsylium" [16].

\section{Powstanie noweyo stanowiska pracy}

Na mocy Uchwały Nr X/98/15 Sejmiku Województwa Lubuskiego z dnia 22 czerwca 2015 roku w sprawie zmiany Statutu Szpitala Wojewódzkiego Samodzielnego Publicznego Zakładu Opieki Zdrowotnej im. Karola Marcinkowskiego w Zielonej Górze dokonano zmian w schemacie organizacyjnym placówki [17]. W szpitalu utworzone zostało nowe, samodzielne stanowisko pracy: koordynator do spraw lecznictwa onkologicznego, podległe bezpośrednio zastępcy dyrektora do spraw lecznictwa. Na stanowisku tym zostały zatrudnione dwie osoby. Podstawowym środowiskiem pracy dla koordynatorów jest szpital, w którym są oni zatrudnieni. Placówka w ramach tak zwanego Lubuskiego Ośrodka Onkologii oferuje swoim pacjentom leczenie w Klinicznym Oddziale i Zakładzie Radioterapii, Klinicznym Oddziale Onkologii czy Dziennym Oddziale Chemioterapii. W strukturach tego szpitala funkcjonują wszystkie niezbędne do realizacji pakietu onkologicznego oddziały zabiegowe oraz zakłady.

\section{Obowiazki koordynatora leczenia onkologiczneyo}

Mimo iż zgodnie z regulaminem organizacyjnym obowiązującym w szpitalu organizacja i obsługa pracy zespołów powołanych przez władze szpitala należy do zadań komórek typowo administracyjnych, w rzeczywistości zadanie to w kontekście konsyliów onkologicznych od samego początku stanowi niezbywalny element pracy koordynatorów. Zasadność tego rozwiązania nie wydaje się podlegać dyskusji, gdyż powierzenie zadania stricte administracyjnemu działowi mijałoby się z celem, a samym koordynatorom zaburzyłoby to rytm ich pracy. Jak dokumentują to obserwacje, częścią koordynacji jest także kierowanie i przypisywanie pacjentów na właściwe konsylia. Odpowiednie przygotowanie dokumentacji na konsylium oraz tak zwana znajomość pacjentów jeszcze przed ułożeniem planu leczenia onkologicznego 
są warunkiem efektywnej pracy koordynatorów [18]. Jak podaje koordynator, w 2015 roku wyjątkową trudność stanowiła kwestia koordynacji leczenia pacjentów cierpiących na nowotwory hematologiczne. W ówczesnym okresie Kliniczny Oddział Hematologii zrezygnował ze zgłaszania pacjentów na konsylium, tym samym z pomocy koordynatorów. Sytuacja ta była spowodowana trudnościami, a raczej brakiem możliwości zapewnienia określonej przepisami liczby specjalistów niezbędnych przy układaniu planu leczenia onkologicznego. W 2017 roku wraz ze zmianami w pakiecie onkologicznym, dotyczącymi między innymi składu konsylium dla pacjentów hematologicznych, problem ten został właściwie rozwiązany w ten sposób, że hematolodzy zaczęli organizować własne konsylia, a funkcję koordynatora objął lekarz prowadzący pacjenta. Tak pozostało do dziś. Według informacji otrzymanej od koordynatora w Szpitalu Uniwersyteckim im. Karola Marcinkowskiego w Zielonej Górze Sp. z o.o. w latach 2015-2018 corocznie odbywało się około 90 posiedzeń Wielodyscyplinarnego Zespołu Terapeutycznego. W 2019 roku liczba konsyliów uległa zwiększeniu, gdyż wyznaczono kolejny dzień posiedzeń konsylium zarezerwowany tylko dla pacjentek ze zdiagnozowanym nowotworem piersi (BCU). Każdego roku ponad 30 uczestniczących w nim na zmianę lekarzy przygotowuje indywidualny plan leczenia onkologicznego dla około 800 pacjentów. W 2019 roku liczba ta uległa zwiększeniu. Od 2015 roku stale rośnie liczba pacjentów, dla których zespół w trakcie leczenia modyfikuje wstępny plan leczenia. Aktualnie dla około 50\% wszystkich pacjentów zwoływane jest kolejne konsylium. Do pełnego zrozumienia tematu istotne jest także przedstawienie zadań wynikających z karty czynności koordynatora. Do podstawowych obowiązków koordynatora zgodnie z obowiązującym w szpitalu regulaminem organizacyjnym należy: koordynowanie realizacji planu leczenia onkologicznego pacjenta ustalonego przez Wielodyscyplinarny Zespół Terapeutyczny, udzielanie pacjentowi informacji o planowanych etapach leczenia onkologicznego określonego $\mathrm{w}$ harmonogramie ustalonym przez Wielodyscyplinarny Zespół Terapeutyczny, ustalanie terminów chemioterapii i radioterapii, wspieranie pacjenta informacyjnie i organizacyjnie, organizowanie współpracy między podmiotami w ramach kompleksowej opieki nad pacjentem, czuwanie nad kompletnością dokumentacji medycznej w zakresie ustalonego planu leczenia onkologicznego oraz przekazywanie karty diagnostyki i leczenia onkologicznego po jej zamknięciu do lekarza podstawowej opieki zdrowotnej [19]. Jak wykazało badanie, praca koordynatora obejmuje także inne inicjatywy, które nie wynikają bezpośrednio z zakresu obowiązków powierzonych tej osobie. Przykładowo, w 2015 roku szpital w osobie koordynatora nawiązał współpracę z realizatorami Programu Edukacji Onkologicznej. Współpraca ta zaowocowała pozyskaniem ponad tysiąca egzemplarzy profesjonalnych poradników dla chorych na raka. Wydane przez Fundację „Tam i z powrotem” bezpłatne poradniki stanowią cenne źródło informacji i są przekazane zarówno na oddziały i do poradni szpitalnych, jak i bezpośrednio pacjentom onkologicznym.

\section{Rozwiazzania informatyczne}

Nadrzędnym zadaniem koordynatora leczenia onkologicznego jest koordynacja procesu leczenia i udzielanie wszechstronnego wsparcia pacjentom. W chwili wejścia w życie Szybkiej Terapii Onkologicznej koordynatorzy nie dysponowali żadnym przygotowanym na ich potrzeby programem informatycznym. Firmy zewnętrzne natychmiast zorientowały się w występującej w tym zakresie luce i oferowały szpitalom wysokopłatne programy informatyczne, które nie służyły celowej koordynacji indywidualnego planu leczenia, natomiast korelowały z elektroniczną wersją karty diagnostyki i leczenia onkologicznego. Oferenci proponowali nawiązanie współpracy w zakresie dostępności programu wspierającego szpitale przy pakiecie onkologicznym. Szpital w Zielonej Górze nie zdecydował się wówczas na nawiązanie współpracy w tym zakresie. Na własne potrzeby koordynator opracował i stale prowadzi własny rejestr pod nazwą „Ruch pacjentów onkologicznych”. Oprócz danych osobowych w rejestrze tym znajdują się dane dotyczące decyzji terapeutycznych, a także informacje o podjętych przez koordynatorów działaniach oraz o sytuacji pacjentów, którzy przeszli przez konsylium i są pod opieką oraz nadzorem koordynatorów.

Uwzględniając złożoność pracy osób zatrudnionych na stanowisku koordynatora, a także biorąc pod uwagę obserwowany trend polegający na rozwoju koordynacji, warto przeanalizować możliwości kształcenia kadr niebędących pracownikami medycznymi, ale mogących wypełniać zadania, za które odpowiadają osoby pełniące funkcję koordynatora organizacyjnego.

\section{Kształcenie kadr}

Na potrzeby artykułu dokonano przeglądu oferty edukacyjnej ukierunkowanej na kształcenie osób mogących pełnić funkcję koordynatorów organizacyjnych. Sytuacja, w której funkcję koordynatora organizacyjnego pełniłyby osoby z wykształceniem medycznym, byłaby oczywiście optymalna. Jednak uwzględniając specyfikę takich zawodów, trudno upatrywać (zwłaszcza w środowiskach lekarzy czy pielęgniarek) osób, które chciałyby zrezygnować ze swoich podstawowych obowiązków na rzecz koordynacji. Przy wyborze zatrudnienia przedstawiciele wymienionych grup zawodowych kierują się chęcią pracy o charakterze zgodnym $\mathrm{z}$ ich podstawowym wykształceniem, stąd prawdopodobny byłby opór przed przejęciem dodatkowych obowiązków wśród przedstawicieli zawodów medycznych. Ponieważ koordynacja, a w konsekwencji przydzielanie tego zadania konkretnym osobom staje się koniecznym wymogiem stawianym świadczeniodawcom, można przypuszczać, że system szkolnictwa dość szybko zareaguje na zmiany zachodzące w sektorze ochrony zdrowia.

Analiza ofert uczelni wyższych dla roku akademickiego 2018/2019 nie ujawniła jednak ani jednej propozycji studiów pierwszego lub drugiego stopnia czy studiów podyplomowych, których ukończenie gwarantowałoby nabycie wszystkich niezbędnych umiejętności 
i kwalifikacji, którymi powinni cechować się koordynatorzy leczenia. Bliskie spełnieniu tych wymagań są uczelnie prowadzące kształcenie studentów na Wydziałach Nauk o Zdrowiu. Absolwenci o takim profilu wydają się studentami, których kwalifikacje w najwyższym stopniu łączą się z profilem koordynatora. Kontynuacją ich wykształcenia mogłyby być specjalistyczne kursy w zakresie diagnostyki i leczenia chorób, których przebieg miałyby te osoby koordynować.

Oferta jednej z uczelni wyższych, to jest Uniwersytetu Śląskiego, może być propozycją dla osób, które rozważają możliwość pracy na stanowisku koordynatora. Jak podaje w swych materiałach uczelnia, w ramach studiów wyższych drugiego stopnia na kierunku coaching medyczny absolwent studiów zyskuje między innymi umiejętność pracy z pacjentem. Coach koncentruje się na indywidualnym kontakcie $\mathrm{z}$ osobami chorymi oraz pomaga im w odkrywaniu, zrozumieniu i osiąganiu celów życiowych. Ponadto może pełnić inną bardzo ważną rolę, mianowicie jego działalność będzie wsparciem dla lekarzy, pielęgniarek i innych osób, które na co dzień pomagają osobom chorym [20].

Nieco bogatsza wydaje się oferta studiów podyplomowych przygotowana przez Uniwersytet Medyczny w Łodzi. Słuchacze studiów podyplomowych na kierunku edukator zdrowotny zyskują szansę nabycia niektórych umiejętności przydatnych w pracy koordynatora. Uniwersytet $\mathrm{w}$ ramach tych studiów zachęca do wyboru spośród następujących specjalności: (1) promocja zdrowia, edukacja zdrowotna oraz profilaktyka cukrzycy i związanych z nią chorób przewlekłych, (2) zarządzanie ochroną zdrowia, (3) ubezpieczenia zdrowotne. Organizatorzy przekonują, że studia te pozwalają uzyskać wiedzę i umiejętności niezbędne do prowadzenia edukacji prozdrowotnej, utrwalania dobrych nawyków żywieniowych oraz dobrej kondycji psychofizycznej, wspierania rodzin i pacjentów $\mathrm{z}$ chorobami przewlekłymi w środowisku szkolnym i zawodowym oraz wsparcia w tym zakresie działań lekarza rodzinnego, diabetologa czy pediatry [21].

Kolejną propozycją kształcenia podyplomowego była oferta zaproponowana przez Uniwersytet Kardynała Stefana Wyszyńskiego w Warszawie, który we współpracy z Polskim Towarzystwem Koordynowanej Ochrony Zdrowia w 2018 roku zachęcał do odbycia studiów podyplomowych łączących praktykę z teorią. Jak można przeczytać na stronach internetowych UKSW, studia te były odpowiedzią na aktualne zapotrzebowanie interesariuszy w ochronie zdrowia w Polsce, a przygotowanie i wdrożenie tego kierunku było wynikiem śledzenia nie tylko trendów, doświadczeń europejskich i światowych, lecz także odpowiedzią na konsekwencje zmian społecznych, demograficznych, ekonomicznych i kulturowych. Zachęcający do odbycia tych studiów podkreślają, że w Polsce potrzebni są profesjonaliści, którzy w szpitalach, poradniach, podstawowej opiece zdrowotnej skoordynują działania i jednocześnie zmniejszą administracyjne obciążenie lekarzy i pielęgniarek oraz pozostałych pracowników medycznych. Wskazują także, że w czasie, kiedy system ochrony zdrowia mierzy się z problemem zmniejszającej się liczby pracujących pielęgniarek, brakiem lekarzy, nieodzowne wydaje się, aby wykonywane przez nich czynności administracyjne zostały przejęte przez menedżerów Koordynowanej Ochrony Zdrowia [22]. Także oferta Wyższej Szkoły Ekologii i Zarządzania w Warszawie dotycząca studiów podyplomowych w zakresie samodzielny koordynator medyczny jest według oferentów odpowiedzią na zmianę w ustawie o świadczeniach pieniężnych z ubezpieczenia społecznego zgłoszoną przez Ministerstwo Rodziny, Pracy i Polityki Społecznej oraz Ministerstwo Zdrowia [23]. Analiza zakresu programowego studiów skłania ku myśleniu, że kierunek ten jest przeznaczony przede wszystkim dla pracowników administracyjno-biurowych.

\section{Koordynacja przzszitościa w ochronie zułowia}

Nową jakością w polskim systemie ochrony zdrowia jest wzmocnienie procesów koordynacji na każdym etapie walki z rakiem. W tym celu potrzebne są liczne zmiany organizacyjne i instytucjonalne oraz powierzenie tego zadania specjalnie w tym celu powołanym osobom. Aktualnie obserwujemy bardzo dynamiczne zmiany w tym zakresie. Walka $\mathrm{z}$ rakiem to także prewencja. $\mathrm{Z}$ roku na rok rośnie świadomość społeczna zagrożeń wywołanych zachorowaniami, ale także rola, jaką pełnią w tej materii specjaliści do spraw zdrowia publicznego.

Szeroko rozumiana funkcja koordynatora jest powiązana z założeniami Strategii Walki z Rakiem w Polsce 2015-2024 [24]. W dokumencie opracowanym wiele lat temu podkreślono potrzebę koordynacji i powierzenia tego zadania konkretnym osobom. Przewidziano w nim między innymi utworzenie lokalnych punktów informacyjnych w każdym z istniejących wojewódzkich ośrodków onkologicznych oraz poza nimi w liczbie 2-3 na województwo i finansowanie ich w ramach lokalnych budżetów obecnie przeznaczonych na programy zdrowotne (działanie 1.6). Przewidziano także przypisanie funkcji koordynatora opieki onkologicznej specjalnie do tego celu powołanym osobom. Już w tamtym okresie istniały plany objęcia szkoleniem uzupełniającym personelu szpitalnego oraz wprowadzenia na wydziałach medycznych wyższych uczelni w szczególności na kierunkach zdrowia publicznego, programów przygotowujących do pełnienia funkcji koordynatora leczenia onkologicznego (działanie 4.3). Ponadto zwrócono uwagę na fakt, że standardem w leczeniu onkologicznym powinno być opracowanie planu leczenia przez wielospecjalistyczny zespół lekarski. Działanie to powinno mieć charakter sformalizowanej czynności zakończonej omówieniem możliwych opcji terapeutycznych i zaproponowaniem ich kolejności. Rekomendowany plan leczenia ma mieć formę oficjalnego dokumentu (działanie 26.1). Zadanie to zostało całkowicie zrealizowane wraz z pojawieniem się w szpitalach pakietu onkologicznego. Skoordynowany model opieki onkologicznej powinien obejmować właściwie wszystkich pacjentów. Opracowanie takiego modelu i jego wdrożenie w znacznym stopniu opiera się na zdefiniowaniu roli i przydzieleniu wyodrębnionym osobom funkcji koordynatora onkologicznego. 
Już wówczas założono, że stanowiska te w początkowym okresie mają powstawać przy istniejących ośrodkach onkologicznych, a następnie poza nimi, a muszą je zajmować odpowiednio przeszkoleni pracownicy medyczni lub absolwenci kierunku zdrowie publiczne. Przeszkolenie koordynatorów należy odbywać według programu opracowanego przez zespół przedstawicieli różnych dyscyplin (działanie 26.2).

\section{Zalety Szybkiej Terapii Onkologicznej}

Najkorzystniejszym skutkiem wprowadzania Szybkiej Terapii Onkologicznej wydaje się konieczność opracowywania indywidualnego planu leczenia onkologicznego przez kilku specjalistów. Z uzyskanych informacji wynika, że w wielu przypadkach decyzje o sposobie leczenia mogłyby być inne, gdyby przy ich podejmowaniu nie uczestniczyli specjaliści z różnych dziedzin. Drugim pozytywnym aspektem Szybkiej Terapii Onkologicznej jest przypisanie pacjentom koordynatora, który pomaga chorym przejść przez wiele skomplikowanych procedur. Pacjenci zwracają się do niego z najróżniejszymi problemami. Dzięki interwencji koordynatora udaje się załatwić wiele spraw, z którymi chorzy sami by sobie nie poradzili. Opinię tę w przeprowadzonych wywiadach potwierdzają sami pacjenci [25]. Koordynator jest łącznikiem między szpitalem, lekarzem a pacjentem. Chorzy oprócz pomocy związanej z organizacją leczenia oczekują często od koordynatorów informacji na temat stanu zdrowia oraz samego procesu leczenia. Problemem, który rzutuje bezpośrednio na opinię i samopoczucie pacjentów, jest kwestia przekazywania informacji. Prawdopodobnie to problem, z którym boryka się zdecydowana większość szpitali w Polsce. W zakresie organizacji systemu opieki zdrowotnej podstawową rolę powinno odgrywać zarządzanie informacją. Ograniczenia dotyczące obiegu informacji utrudniają koordynację i przepływ danych między uczestnikami procesu terapeutycznego. W przypadku pacjentów onkologicznych stanowi to często bardzo duże obciążenie.

\section{Podsumowanie}

Opieka koordynowana to pojęcie, które nie jest wprawdzie tożsame, ale bardzo często łączy się z koordynatorem. Liczne publikacje wskazują na znaczenie organizacji kompleksowej i zintegrowanej opieki zdrowotnej, upatrując w niej zarówno źródeł efektywności ekonomicznej, poprawy wyników leczenia, jak i wzrostu zadowolenia samych pacjentów. W tekście podkreślona została nowatorska rola systemu placówek Breast Cancer Unit oraz złożoność prowadzonych w jego ramach procesów opieki medycznej. Prowadzi to do wniosku o konieczności umocnienia roli koordynatorów leczenia onkologicznego, których zadaniem jest optymalizacja leczenia. Doświadczenia ostatnich lat poparte praktyką koordynatorów pokazały, że koordynacja musi być przypisana konkretnej osobie optymalizującej proces leczenia realizowany przez różnych specjalistów. Podjęcie próby zdefiniowania i określenia tej funkcji w kategoriach specjalności w dziedzinach mających zastosowanie $\mathrm{w}$ ochronie zdrowia jest prawdopodobnie kwestią czasu, tak samo jak rozpoczęcie ekspansywnego kształcenia przyszłych koordynatorów. W czasach dużych zmian w podejściu do leczenia oraz ogromnych deficytów pracowników medycznych zasadne wydaje się zainicjowanie dyskursu na temat możliwości wprowadzania nowego zawodu, to jest koordynatora leczenia.

\section{Piśmiennictwo}

1. Nowotwory w liczbach. Coraz więcej chorych na raka, 2019; Medonet.pl, http://www.medonet.pl/zdrowie,nowotwory-w-liczbach--coraz-wiecej-chorych-na-raka,artykul,1724523. html (dostęp: 12.08.2019).

2. Nowotwory złośliwe ogółem, 2019, Krajowy Rejestr Nowotworów; Onkologia.org.pl, http://onkologia.org.pl/nowotwory-zlosliwe-ogolem-2/ (dostęp: 12.08.2019).

3. Dunn N. (red.), Opowieści o raku. Sztuka komunikacji w opiece onkologicznej, Via Medica, Gdańsk 2009.

4. Ustawa z dnia 27 sierpnia 2004 roku o świadczeniach opieki zdrowotnej finansowanych ze środków publicznych (Dz.U. z 2004 roku Nr 210 poz. 2135 z późn. zm.).

5. Rozporządzenie Ministra Zdrowia z dnia 22 listopada 2013 roku w sprawie świadczeń gwarantowanych z zakresu leczenia szpitalnego (Dz.U. z 2013 roku poz. 1520 z późn. zm.).

6. Rozporządzenie Ministra Zdrowia z dnia 6 listopada 2013 roku w sprawie świadczeń gwarantowanych z zakresu ambulatoryjnej opieki specjalistycznej (Dz.U. z 2013 roku poz. 1413 z późn. zm.).

7. Regulamin Organizacyjny Szpitala Uniwersyteckiego imienia Karola Marcinkowskiego w Zielonej Górze Spółka z ograniczoną odpowiedzialnością; szpital.zgo.pl, http://bip. szpital.zgo.pl/index.php?id=129186 (dostęp: 18.08.2019).

8. Uchwała nr X/98/15 Sejmiku Województwa Lubuskiego z dnia 22 czerwca 2015 roku w sprawie zmiany Statutu Szpitala Wojewódzkiego Samodzielnego Publicznego Zakładu Opieki Zdrowotnej im. Karola Marcinkowskiego w Zielonej Górze; dzienniki.luw.pl, http://dzienniki.luw.pl/ Compatible/Details?Oid=18387 (dostęp: 16.08.2019).

9. Breast Cancer Unit - interdyscyplinarne leczenie raka; zwrotnik raka.pl, https://www.zwrotnikraka.pl/leczenie-raka-piersi-breast-cancer-unit/ (dostęp: 15.08.2019).

10. Chaudary M.A., Millis R.R., Hoskins E.O.L. Halder M., Bulbrook R.D., Cuzick J., Hayward J.L., Bilateral primary breast cancer: A prospective study of disease incidence, „British Journal of Surgery” 1984; 71: 711-714.

11. Breast Cancer Unit to nowa jakość opieki dla pacjentów z nowotworem piersi, 2019; rynekzdrowia.pl, http://www. rynekzdrowia.pl/Serwis-Onkologia/MZ-Breast-Cancer-Unit-to-nowa-jakosc-opieki-dla-pacjentow-z-nowotworem-piersi,195092,1013.html (dostęp: 12.09.2019).

12. Rozporządzenie Ministra Zdrowia z dnia 24 maja 2019 roku zmieniające rozporządzenie w sprawie świadczeń gwarantowanych z zakresu leczenia szpitalnego (Dz.U. z 2019 roku poz. 1062).

13. Rozporządzenie Ministra Zdrowia z dnia 23 maja 2019 roku zmieniające rozporządzenie w sprawie świadczeń gwarantowanych z zakresu ambulatoryjnej opieki specjalistycznej (Dz.U. z 2019 roku poz. 1060). 
14. Ustawa $\mathrm{z}$ dnia 9 marca 2017 roku o zmianie ustawy o świadczeniach opieki zdrowotnej finansowanych ze środków publicznych (Dz.U. z dnia 11 kwietnia 2017 r. poz. 759).

15. Rudawska I., Zintegrowana Opieka Zdrowotna. Podejście relacyjne do obstugi pacjenta jako klienta, Wolters Kluwer SA, Warszawa 2014.

16. Zarządzenie nr 207/2017 Prezesa Zarządu Szpitala Uniwersyteckiego imienia Karola Marcinkowskiego w Zielonej Górze Sp. z o.o. z dnia 11 grudnia 2017 roku w sprawie procedury postępowania i organizacji udzielania świadczeń na rzecz pacjentów leczonych na podstawie karty diagnostyki i leczenia onkologicznego (aktualne na dzień 12.09.2019).

17. Uchwała nr X/98/15 Sejmiku Województwa Lubuskiego z dnia 22 czerwca 2015 roku w sprawie zmiany Statutu Szpitala Wojewódzkiego Samodzielnego Publicznego Zakładu Opieki Zdrowotnej im. Karola Marcinkowskiego w Zielonej Górze; Dzienniki.luw.pl, http://dzienniki.luw. pl/Compatible/Details?Oid=18387 (dostęp: 16.08.2019).

18. Kita A., Założone i rzeczywiste funkcje koordynatora leczenia onkologicznego $w$ polskim systemie ochrony zdrowia, „Psychoonkologia” 2018; 22 (3): 107-112.
19. Regulamin Organizacyjny Szpitala Uniwersyteckiego im. Karola Marcinkowskiego w Zielonej Górze Spółka z ograniczoną odpowiedzialnością; szpital.zgora.pl, http://bip. szpital.zgo.pl/index.php?id=129186 (dostęp: 18.08.2019).

20. Wydział Nauk o Zdrowiu Śląski Uniwersytet Medyczny w Katowicach. Kierunki Studiów; otouczelnie.pl, https://www.otouczelnie.pl/wydzial/196/Wydzial-Nauk-o-Zdrowiu (dostęp: 17.08.2019).

21. Kształcenie podyplomowe; naukiozdrowiu.umed.lodz.pl, http://naukiozdrowiu.umed.lodz.pl/ksztalcenie-podyplomowe/ (dostęp: 17.08.2019).

22. Studia podyplomowe; wnhis.uksw.edu.pl, http://is.wnhis. uksw.edu.pl/node/908 (dostęp: 17.08.2019).

23. Studia Podyplomowe - Samodzielny koordynator medyczny; wseiz.uksw.edu.pl, http://www.wseiz.pl/pl/studia-podyplomowe/studiapodyplomowe-samodzielny-koordynator-medyczny (dostęp:15.08.2019).

24. Strategia Walki z Rakiem w Polsce 2015-2024; walka z rakiem.pl, http://www.walkazrakiem.pl/strategia-walki-z-rakiem-w-polsce-2015-2024 (dostęp: 11.08.2019).

25. Indywidualne wywiady niestrukturyzowane, realizowane w ramach własnego projektu badawczego (2015-2019). 